\title{
Review Article \\ Emerging Persistent Organic Pollutants in Chinese Bohai Sea and Its Coastal Regions
}

\author{
Xiaomin Li, ${ }^{1}$ Yan Gao, ${ }^{2}$ Yawei Wang, ${ }^{2}$ and Yuanyuan Pan $^{3}$ \\ ${ }^{1}$ Institute of Quality Standard and Testing Technology for Agro-Products, The Chinese Academy of Agricultural Sciences (CAAS), \\ Beijing 100081, China \\ ${ }^{2}$ State Key Laboratory of Environmental Chemistry and Ecotoxicology, Research Center for Eco-Environmental Sciences, \\ Chinese Academy of Sciences, Beijing 100085, China \\ ${ }^{3}$ Thermo Fisher Scientific, Room 214, Tianchuang Science and Technology Building, No. 8 Caihefang Road, Haidian District, \\ Beijing 100080, China
}

Correspondence should be addressed to Xiaomin Li; lixiaomin@caas.cn

Received 26 August 2013; Accepted 21 October 2013; Published 3 February 2014

Academic Editors: S. K. Akal Solmaz and P. Szefer

Copyright (C) 2014 Xiaomin Li et al. This is an open access article distributed under the Creative Commons Attribution License, which permits unrestricted use, distribution, and reproduction in any medium, provided the original work is properly cited.

\begin{abstract}
Emerging persistent organic pollutants (POPs) have widely aroused public concern in recent years. Polybrominated diphenyl ethers (PBDEs) and perfluorooctane sulfonyl fluoride/perfluorooctane sulfonic acid (POSF/PFOS) had been newly listed in Stockholm Convention in 2009, and short chain chlorinated paraffins (SCCPs) and hexabromocyclododecanes (HBCDs) were listed as candidate POPs. Bohai Sea is located in the arms of numbers of industrial cities, the semienclosed location of which makes it an ideal sink of emerging pollutants. In the present paper, latest contamination status of emerging POPs in Bohai Sea was reviewed. According to the literature data, Bohai Sea areas are not heavily contaminated by emerging POPs (PBDE: 0.01-720 ng/g; perfluorinated compounds: 0.1-304 ng/g; SCCPs: 64.9-5510 ng/g; HBCDs: nd-634 ng/g). Therefore, humans are not likely to be under serious risk of emerging POPs exposure through consuming seafood from Bohai Sea. However, the ubiquitous occurrence of emerging POPs in Bohai Sea region might indicate that more work should be done to expand the knowledge about potential risk of emerging POPs pollution.
\end{abstract}

\section{Introduction}

A dozen of organic pollutants, including eight types of organochlorine pesticides (OCPs), two types of industrial chemicals (polychlorinated biphenyls (PCBs) and hexachlorobenzene (HCB)), and two types of byproducts (polychlorinated dibenzo-p-dioxins (PCDD) and polychlorinated dibenzofurans (PCDF), have been restricted as "legacy persistent organic pollutants (POPs)" by the Stockholm Convention in 2001. Due to POPs' physical and chemical properties, they are (1) environmental persistent; (2) widely distributed throughout the environment; (3) accumulate through food chain including humans; (4) toxic to humans and wildlife [1]. Stockholm Convention is open to compounds which have met the screening criteria for POPs.
Emerging contaminants are presently referred to as pharmaceuticals and personal-care products, drugs of abuse, steroids and hormones, surfactants, flame retardants, industrial additives and agents, and so on [2-4], among which polybromodiphenyl ether (PBDEs), perfluorinated compounds (PFCs), short-chained chlorinated paraffins (SCCPs), and hexabromocyclododecane (HBCDs) were the most concerned. With the process of the work of POPs review committee, nine types emerging organic pollutants including perfluorooctane sulfonic acid (PFOS), commercial pentabromodiphenyl ether (penta-BDE), and commercial octabromodiphenyl ether (octa-BDE) have already been added to Stockholm Convention in 2009. Recently, SCCPs, HBCDs and other three emerging contaminants were proposed for being listed under the Convention. 


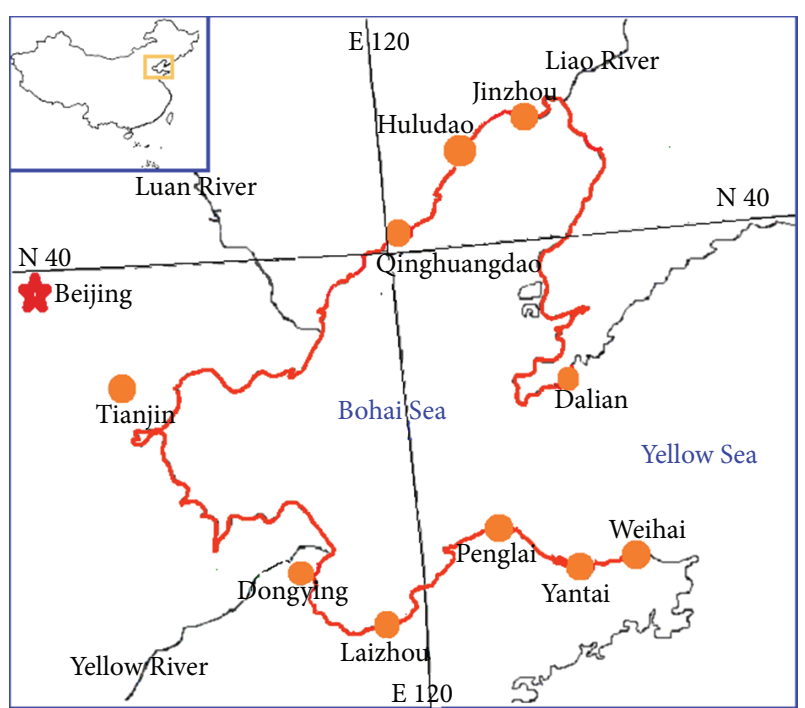

FIgURE 1: Main cities and rivers around Bohai Sea.

China is a big country in producing and using chemicals, and the pollution problem of legacy POPs has continuously attracted public attention. Candidate POPs, also called "emerging POPs," have become a hotspot in the environmental research and management.

Chinese Bohai Sea is located within the arms of Liaodong and Shandong Peninsula (Figure 1) and is considered to be one of the most POPs polluted areas in the world. As one of the most developed regions in China, it is embraced by several metropolises, such as Beijing, Tianjin, and Dalian. Several rivers empty into Bohai Sea, meaning that the industrial and municipal wastewater from the surrounding cities is also discharged into it. In addition, the semienclosed terrain makes the water exchange between Bohai Sea and the open ocean relatively slow. Thus, pollutants in Bohai Sea are difficult to diffuse. Bohai Sea has become one of the most heavily polluted sea areas in China at present and might act as a sink of many pollutants including POPs [5-7]. However, Bohai Sea is one of the most important fisheries in China. It provides amounts of seafood to peripheral cities. Therefore the pollution in Bohai Sea had caused great concerns in the past decades. Many studies have focused on the pollution status of various chemicals such as heavy metals, organic metals, OCPs, and PCBs [5, 8-11]. As a very good bioindicator, a series of works of pollutants in mollusks along the coastline of the Bohai Sea has been reported since 2000s. Liang et al. [5] evaluated mollusks as biomonitors to investigate heavy metal contaminations along the Chinese Bohai Sea in 2004; Wang et al. [10] further studied the correlations among heavy metals in mollusks samples. The speciation of several heavy metals in mollusks such as mercury and tin was also studied. Liang et al. [8] evaluated the methylmercury and total mercury contents in gastropod and bivalve species from Chinese Bohai Sea. Yang et al. $[12,13]$ studied the distribution and temporal trends of butyltins monitored by mollusks along the Chinese Bohai coast and found that the concentrations of the concentration of butyltins kept high in mollusks during the sampling period of 2002 2005.

Some emerging pollutants such as PBDEs, SCCPs, and PFCs have been proved to be global pollutants. They were not only found in industrial areas but were also detected in remote areas such as Polar Regions and Tibet Plateau. This review have summarized and analyzed monitoring data available of main emerging POPs in Bohai Sea from peer-reviewed papers. Though these pollutants were analyzed by different analytical methods in various environmental media, the contamination status of emerging POPs and relative levels among legacy POPs and emerging POPs still should be clarified.

\section{Analytical Methodologies}

Emerging POPs usually exist at trace or ultratrace levels in environment; thus specific pretreatment and sensitive detection instrument are indispensable. According to the currently reported analytical methods for the most frequently studied emerging POPs, mass spectrometric detector was widely applied. Generally, chemicals with high volatility and thermal stability such as PBDEs and SCCPs were usually detected by GC-MS ${ }^{n}$, and those with high water solubility and/or polarity such as PFCs and HBCDs were analyzed by HPLC-MS [2].

\section{Distributions of Emerging POPs in Water Body and Sediments}

Sediment is viewed as an important sink of all the pollutants. Sediment contamination is essential in assessing the impact of human activities on aquatic systems. Pollutants which are released into water body will reach a dynamic balance between water phase and sediment. Besides, benthonic organisms such as mollusks can accumulate toxicants and introduce them to the food web from sediment and water phase; thus sediment plays a significant role in evaluating the overall environmental quality of an aquatic system.

3.1. PBDEs. PBDEs were additive brominated flame retardants which have been widely used around the world. Wang et al. [14] investigated congener profiles and pollution levels of PBDEs in sediment along the coast of Bohai Sea. The median values of BDE 209 and total PBDEs (including BDE $17,28,47,66,71,85,99,100,138,153,154,183$, and 190) were 2290 and $160 \mathrm{pg} / \mathrm{g}$ dry weight (dw) in sediments. Clearly, BDE 209 was the predominant congener in sediments. Pan et al. [15] examined PBDEs in 44 surface sediments from Bohai Sea. It has been found that the pollution level of seven major PBDEs (BDE 28, 47, 99, 100, 153, 154, and 183) ranged from 220 to $900 \mathrm{pg} / \mathrm{g} \mathrm{dw}$ with an average of $480 \mathrm{pg} / \mathrm{g} \mathrm{dw}$. This is comparable to another semiclosed sea [16]. They also observed an average BDE 209 concentration of $7000 \mathrm{pg} / \mathrm{g} \mathrm{dw}$, which was one order of magnitude higher than the other BDE congeners. Besides, high levels of PBDEs were detected in sediments from river estuaries, which proved that the input generated by anthropogenic activities is one of the main sources of PBDEs in Bohai Sea. Further, Pan et al. studied the PBDE profiles in riverine and marine sediments 
of the Laizhou Bay. It is located in the southern Bohai Sea [17] and considered the largest manufacturing base of brominated flame retardants in Asia. The results showed that BDE 209 and the sum of other seven PBDE congeners in marine sediments ranged from 660 to $12000 \mathrm{pg} / \mathrm{g}$ and not detected (nd) to $660 \mathrm{pg} / \mathrm{g}$, respectively. PBDEs contents in riverine sediments were higher than those in marine sediments, which might suggest the contributions of BFR manufacturing base. However, concentrations of PBDEs in both riverine and marine sediments were not at a peak value around the world. Zheng et al. [18] studied the PBDEs levels and profiles in the main riverine, estuarine, and intertidal zone sediments along the Bohai Bay coastline in 2007. PBDEs concentration in sediments ranged from nd to $870 \mathrm{pg} / \mathrm{g} \mathrm{dw}$. Similar to previous studies, higher levels of PBDEs were found in the sediments at the outlet of Haihe, Dagu Drainage Rivers, and Yongdingxinhe River. These results suggested that surface runoff might be one of the main introducing pathways of PBDEs into Bohai Sea. Zhao et al. [19] studied PBDEs distributions in three intertidal sediments (Qikou, Lujuhe, and Dagukou) according to grain size. No significant difference was found among fractions. The total PBDEs in sediment ranged from 56 to $300 \mathrm{pg} / \mathrm{g} \mathrm{dw}$, which were slightly lower than Pan et al's [15] study. Zhao et al. [20] investigated the concentrations, profiles, and possible sources of PBDEs in Daliao River estuary on north Bohai Sea coastline. The level of PBDEs in sediments was within the ranges of above studies. All the above studies confirmed that BDE 209 was the dominant congener in sediments, which indicated that commercial deca-BDE product might be the main source in Bohai Sea area, and the use of penta- and octa- BDE contained products that also exist.

3.2. PFCs. PFCs, especially PFOS and perfluorooctanoic acid (PFOA), have received considerable attention due to their persistence and ubiquitous existence in environment. Up to now, the information about PFCs distribution in the sediments from Bohai Sea is still limited, but several papers reported present PFCs distribution in waters and sediments of the rivers flowing to Bohai Sea. Chen et al. [21] investigated 15 perfluorinated compounds in water samples and corresponding surface sediments from outlets of rivers in coastal regions of Bohai Sea and found that PFOS and PFOA were the predominant PFCs in water samples. Compared to the reports of other places, total PFCs concentrations in most samples in this area were relatively low and the highest levels of PFOS and PFOA were, respectively, 31 and $82 \mathrm{ng} / \mathrm{L}$. According to the geographical distribution of city and industry in their sampling areas, Chen et al. attributed the high levels of PFCs in some sampling sites to the industrial wastewater and domestic sewage discharge from cities, which was consistent with the findings by Becker et al. [22]. Generally, PFCs in sediment samples are higher than in water samples, and PFUnA is detected more frequently in sediment than PFOS and PFOA, which might indicate that sediment is a sink of long carbon chain PFCs. Wang et al. studied PFCs profiles in main riverine and estuarine around Bohai Sea area [23, 24]. PFCs levels in Liaohe River were significantly higher than other locations in North Bohai Sea coastline. Specifically, the PFCs level in water samples were consistent with Chen et al's study [21], and the concentrations of PFOS and PFOA in riverine sediments were in the range of $<0.1$ to $2.0 \mathrm{ng} / \mathrm{g} \mathrm{dw}$ and $<0.1$ to $0.5 \mathrm{ng} / \mathrm{g} \mathrm{dw}$, respectively. In a coastal industrial area of Tianjin, concentrations of PFCs in surface waters and sediments ranged from 4.4 to $25 \mathrm{ng} / \mathrm{L}$ and 1.5 to $7.8 \mathrm{ng} / \mathrm{g} \mathrm{dw}$, respectively. All water samples contained detectable concentrations of PFOS and PFOA, while PFDoA and PFUnA were found to be ubiquitous in sediments. PFDoA ranged from 0.27 to $0.81 \mathrm{ng} / \mathrm{g}$ dw in sediment, with an average of $0.48 \mathrm{ng} / \mathrm{g} \mathrm{dw}$. In addition to direct input to Bohai Sea through surface runoff, precipitation events might be another source of PFCs. Liu et al. [25] analyzed PFCs in rain and snow samples in Dalian; they found a geometric mean $145 \mathrm{ng} / \mathrm{L}$ for PFOS and $24.7 \mathrm{ng} / \mathrm{L}$ for PFOA during the snow event. Ju et al. [26] measured PFOS and PFOA levels in Dalian coastal waters; the geometric means of PFOS and PFOA were 0.18 and $0.69 \mathrm{ng} / \mathrm{L}$, respectively. Further, they found that PFCs concentrations in sea surface microlayer samples were significantly higher than surface water and subsurface water because of surfactant properties of PFCs.

3.3. Other Pollutants. Polychlorinated naphthalenes (PCNs) and HBCDs have been proposed as candidate compounds to the Convention recently. However, there are only a few reports about the pollution status of these emerging POPs in Bohai Sea. Pan et al. [27] analyzed PCNs in sediments from Laizhou Bay area. Concentrations of PCNs in marine and riverine sediments ranged from 0.06 to $0.47 \mathrm{ng} / \mathrm{g} \mathrm{dw}$ and 0.05 to $5.1 \mathrm{ng} / \mathrm{g} \mathrm{dw}$, respectively. PCNs in marine sediments were slightly lower than those in Qingdao coast (located at the rim of an open ocean), and the latter ranged from 0.21 to $1.21 \mathrm{ng} / \mathrm{g} \mathrm{dw}$. The average concentration in riverine sediments was approximately 4 times higher than those in marine sediments ( 1.1 versus $0.26 \mathrm{ng} / \mathrm{g} \mathrm{dw}$ ), indicating the diffusion of PCNs from land to marine. Zhao et al. [28] investigated PCNs concentrations in sediments from the Daliao River Estuary. Total concentrations of PCNs in north Bohai Sea coastline were in the range of $0.03-0.28 \mathrm{ng} / \mathrm{g} \mathrm{dw}$, which were comparable to Laizhou Bay located in south Bohai Sea coastline [27]. Compared with other areas in China, sediment PCNs concentrations in Bohai Sea were similar to that in Yangtze River Estuary $(0.03-0.30 \mathrm{ng} / \mathrm{g} \mathrm{dw})$, Qingdao coast $(0.21-1.21 \mathrm{ng} / \mathrm{g} \mathrm{dw})$, and Yellow River Estuary $(0.006-0.41 \mathrm{ng} / \mathrm{g} \mathrm{dw}[29,30]$. Globally, PCNs in sediments were relatively low compared to North America [31], and the possible reason might be that commercial PCNs have never been historically produced in China. Zhang et al. have lately reported the concentrations of HBCDs in the sediment from Tianjin (Haihe River, Dagu Drainage Canal, and Tianjin Harbor), which filled the gap of HBCD study in this area [32]. The concentration of HBCD in the sediment turned out to be a very high value, which has reached $634 \mathrm{ng} / \mathrm{g}$. HBCDs levels in riverine sediments in Laizhou Bay area, which is the biggest brominated chemical industry base in China, were reported by $\mathrm{Li}$ et al. [33]. The highest concentrations in sediment samples reached $1029 \mathrm{ng} / \mathrm{g} \mathrm{dw}$, which was obviously influenced by the production activities in local area. 


\section{Distribution of Emerging POPs in Biota}

POPs can accumulate in the biota due to their hydrophobic and lipophilic characteristics and finally expose high health risk on higher-trophic-level organisms including humans via biomagnifications through food chains. The toxicities of emerging organic pollutants were not clear at present stage, and the levels of these pollutants in biota especially in edible organisms should be carefully concerned. Aquatic organisms such as mollusks and fishes have been proved to be good pollutants and risk indicators. They can reflect the contamination level in their surrounding environment such as water and sediment and also can evaluate the health risk on humans who intake the pollutants through seafood consumption [34].

4.1. PBDEs. Wang et al. [35] measured the levels, profiles, and distribution of PBDEs in mollusks of Bohai Sea from 2006 to 2007. PBDEs could be detected in all samples, which indicated the PBDEs' ubiquity in environment. The sum of 12 PBDEs (BDE17, 28, 47, 66, 71, 85, 99, 100, 138, 153, 154, and 183) ranged from 0.11 to $61 \mathrm{ng} / \mathrm{g} \mathrm{dw}$ in 2006 and from 0.04 to $4.4 \mathrm{ng} / \mathrm{g}$ in 2007. In addition, PBDEs in mollusk samples collected from southern coastline were higher than those from northern coastline, which might be due to the disseminated BFR manufacturing industries on the southern coastline. In the recent study by the same group [36], the PBDEs in 131 mollusk samples collected in 2009 and 2010 were analyzed, and the concentrations ranged from 0.01 to $20.4 \mathrm{ng} / \mathrm{g} \mathrm{dw}$ with a mean of $1.39 \mathrm{ng} / \mathrm{g} \mathrm{dw}$. They found that PBDE in mollusks decreased from $7.0 \mathrm{ng} / \mathrm{g} \mathrm{dw}$ in 2003 to $1.0 \mathrm{ng} / \mathrm{g} \mathrm{dw}$ in 2010. The downward trends might be due to the phasing out of penta- and octa-BDEs commercial products on a global scale and the restriction of PBDEs in China since 2006. Jin et al. [37] reported that PBDEs levels in four species of shellfish from Laizhou Bay ranged from 230 to $720 \mathrm{ng} / \mathrm{g}$ lipid weight. Wan et al. [38] analyzed 13 PBDEs congeners in different trophic levels (including zooplankton, invertebrate species, fishes, and marine birds) in Bohai Sea ecosystem. Total PBDEs contents in biota from Bohai Bay ranged from 0.15 to $32.8 \mathrm{ng} / \mathrm{g}$ lipid. BDE 47 was the predominant congener in most samples. Furthermore, biomagnifcation of PBDE in the marine food web is confirmed by stable nitrogen isotope technologies in the samples from Chinese Bohai Bay. Liu et al. [39] determined the levels of PBDEs in marine fish from all the four seas of China and the average of total PBDEs (exclude BDE 209) and BDE 209 concentration in fish from Bohai Sea was 24 and $12 \mathrm{ng} / \mathrm{g}$ wet weight (ww), respectively, which was lower than that in Yellow Sea and East China Sea. But PBDE contents in fish were relatively higher compared with those in mollusk samples [14, 35-37]. Another study on PBDEs in invertebrate and fish species collected from Bohai Bay from 2007 to 2008 [40] indicated that the concentrations of the six major PBDE congeners (BDE 28, 47, 99, 100, 153, 154) in fish were significantly higher than in invertebrates, which also proved the biomagnification of PBDEs in marine food web. Different from sediments, BDE 209 was not the predominant congener in biota samples and even below detection limits in some samples. This is consistent with the basic fact of the lower bioavailability and chemical stability of BDE 209. One exception is reported by Wang et al. [14], who found that BDE 209 was the major congener in mussel samples from Bohai Sea and the median of BDE 209 in mussels was about 4 times higher than that in sediments (2.43 versus $0.68 \mathrm{ng} / \mathrm{g} \mathrm{dw}$ ).

4.2. PFCs. The presence of PFCs was reported in biota samples from Bohai Sea, while PFOS and PFOA were major PFCs in biota. Pan et al. [41] first reported nine PFC compounds' levels in eleven mollusk species (soft tissues) which were collected from nine coastal cities along the Chinese Bohai Sea. PFOA was the predominant PFCs, followed by PFOS in 137 mollusk samples. Mean concentrations of PFOA and PFOS in different species ranged from $<0.5$ to 31.3 and 0.22 to $1.24 \mathrm{ng} / \mathrm{g} \mathrm{dw}$, individually. The concentrations of PFOA in mollusks were significantly correlated with those of PFOS, which indicated a common source of the two compounds in this region. Chen et al. [42] reported that the mean concentration of PFOS (1.78 ng/g ww) in wild marine crabs from Hangu (Tianjin) was slightly higher than that in mollusks. Yang et al. [43] measured 10 PFCs in seafood collected from Bohai Bay, including 8 invertebrate species and 6 fishes. Organ distribution indicated that PFCs were preferentially distributed in the liver or viscera in seafood. Total PFCs in invertebrates and fishes ranged from nd to $194 \mathrm{ng} / \mathrm{g} \mathrm{dw}$ and 4.0 to $304 \mathrm{ng} / \mathrm{g}$, respectively. Concentrations of PFCs in fish were greater than those in other species of lower trophic levels such as mollusks and invertebrates, which might suggest biomagnification process of PFCs in the food web of Bohai Sea.

4.3. Other Pollutants. Recently, not only the PFCs and PBDEs but also several other emerging POPs in mollusk samples from Bohai Sea were investigated. It included several types of BFCs and SCCPs. Zhu et al. [36] analyzed HBCDs and a novel $\mathrm{BFC}$, tris(2,3-dibromopropyl) isocyanurate (TBC), in nine bivalve and two gastropod species collected from nine coastal cities around the Bohai Sea in 2009 and 2010. Concentrations of HBCDs and TBC ranged from nd to $28.8 \mathrm{ng} / \mathrm{g} \mathrm{dw}$ and nd to $12.1 \mathrm{ng} / \mathrm{g} \mathrm{dw}$. The detection frequencies of HBCDs and TBC reached $99 \%$ and $77 \%$ in mollusks, indicating wide distribution of these two emerging POPs in Bohai Sea region. Yuan et al. [44] examined SCCPs contents in the same batch of mollusk samples and evaluated the spatial distributions and potential factors influencing the bioaccumulation. Concentrations of total SCCPs were in the range $64.9 \sim 5510 \mathrm{ng} / \mathrm{g} \mathrm{dw}$ in the mollusks. Six and seven chlorinated substituents were the main congener groups in mollusks, with an average chlorine content of $61.1 \%$. According to the carbon chain length, SCCPs with 10 and 11 carbon atoms were the predominant homologue groups, accounting for about $29.7 \%$ and $34.9 \%$ of the total SCCPs, respectively. Mya arenaria, Mactra veneriformis, and oyster could be selected as potential bioindicators for investigating SCCPs contamination in the coastal region.

\section{Comparison of Emerging Organic Pollutants between Bohai Sea and Worldwide}

The pollution status of both legacy and emerging pollutants in the Bohai Sea area has been summarized in Figures 2(a) and 2(b). Compared to legacy POPs, levels of emerging 


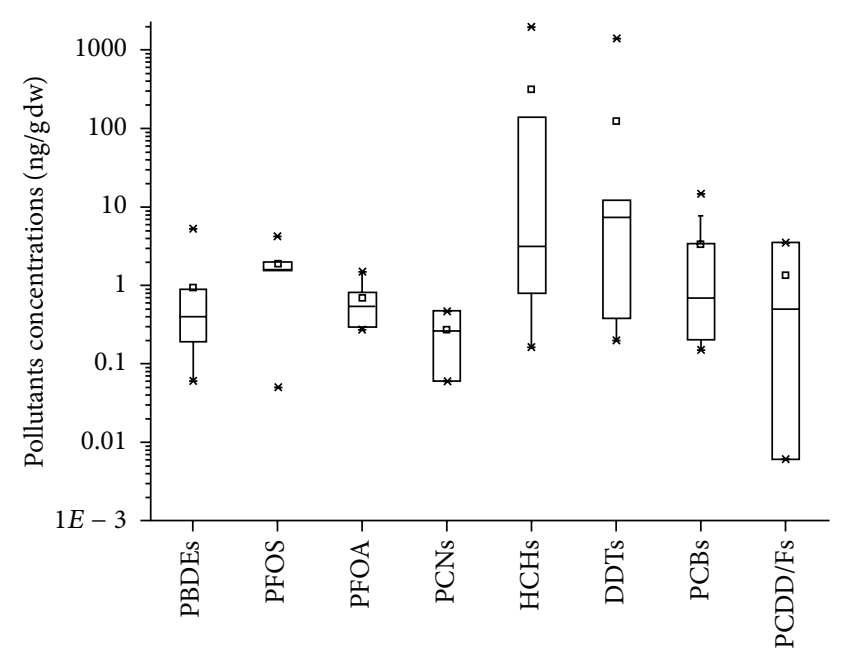

(a)

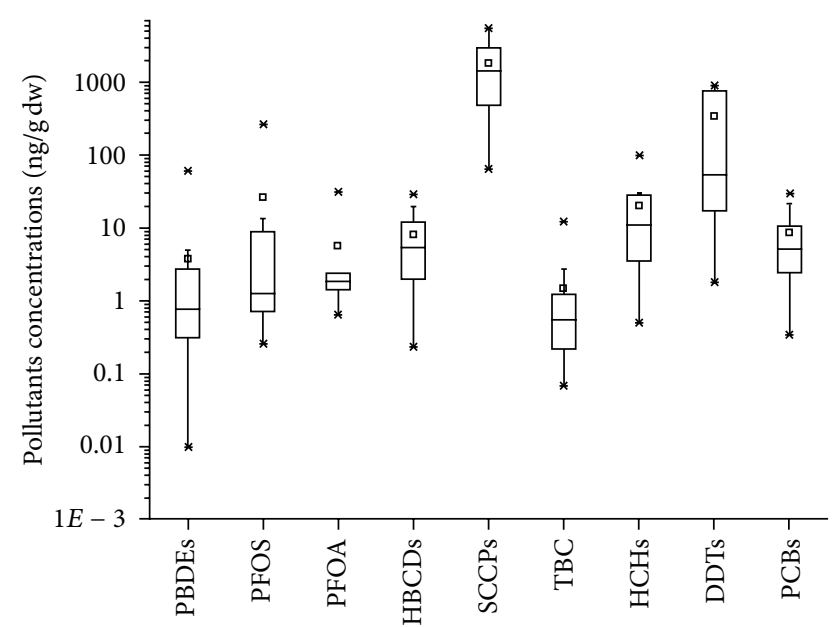

(b)

FIGURE 2: (a) Legacy POPs and emerging pollutants in Bohai Sea sediments. The upper and lower quartiles of the boxes represent 25th and 75 th percentiles of the data, and three horizontal bars represent the maximum, median, and minimum values; " $\times$ " and " $\square$ " denotes outliers and mean. (Data source: PBDEs [14, 15, 17, 18, 20]; PFOS [23, 24]; PFOA [23, 24]; PCNs [27]; HCHs [6, 84, 85]; DDTs [6, 85-88]; PCBs $[15,19,87,89]$; PCDD/Fs $[84,89])$. (b) Legacy POPs and emerging pollutants in Bohai Sea organisms. The upper and lower quartiles of the boxes represent 25 th and 75th percentiles of the data, and three horizontal bars represent the maximum, median, and minimum values; " $x$ " and "в" denotes outliers and mean. (Data source: PBDEs [14, 35-37, 40]; PFOS [23, 41]; PFOA [23, 41]; HBCDs [36]; SCCPs [44]; TBC [36]; HCHs $[9,35,37]$; DDTs $[9,52]$; PCBs $[11,35])$.

pollutants (PBDEs, PFOS, PFOA, and PCNs) in sediments were lower than organochorine pesticides (HCHs and DDTs) but were comparable to PCBs and PCDD/Fs (Figure 2(a)). Figure 2(b) showed the status of pollutants in biota samples from Bohai Sea, among which, the level of SCCPs was the highest, followed by the order of organochorine pesticides (DDTs, HCHs) > PCBs, PFOS, HBCDs > PFOA, PBDEs, TBC. The PBDE concentrations in sediments and organism in the Bohai Sea were comparable to those from other sea areas of China. PFCs levels in sediments from Bohai Sea also showed similarity to other sea areas in China. But in biota samples, PFCs levels were slightly higher in Bohai Sea, which might be due to its semiclosed topography and the contribution of several local rivers intensively affected by human activities [22]. Emerging persistent pollutants levels in developed countries' coast (such as USA and Japan) and remote areas (such as north Norway, Greenland Island, and Canada) were also listed to make a comparison to the Bohai Sea (Table 1). On the whole, PBDEs levels in samples from Bohai Sea area were lower than those from North America, which might be due to the large usage amount of PBDEs in the continent [45]. Even at the most contaminated sites in Bohai Sea area (Laizhou Bay) [17], PBDEs level in sediments were still lower than that in the USA $[46,47]$. PFOS and PFOA in Bohai Sea area were comparable to foreign contamination level $[46,47]$ except those in Arctic area [48].

\section{Conclusions and Perspectives}

Emerging POPs have aroused wide public concern in recent years. The present study reviewed the status and congener profiles of emerging organic pollutants in the Chinese Bohai
Sea, which is surrounded by several metropolises. Surprisingly, the pollution levels of some kinds of emerging organic pollutants (PFOS, HBCDs) in organisms were comparable to some legacy POPs, although the former has been paid attention to recently. Besides, the emerging pollutants also exhibited ubiquitous existence in both abiotic and biotic media. Such results suggested that the emerging organic pollutants in Bohai Sea should arouse our attention. Moreover, some of these pollutants are bioaccumulative and biomagnified through food web and finally can expose high risk to human beings. Though the data in Figure 2 come from different studies, they have shown some consistency: the average values of PBDEs, PFOS, and PFOA were higher in organism than those in sediments, which indicated bioaccumulation behavior of these emerging chemicals (organism versus sediment: 3.85 versus 0.94 for PBDEs, 26.35 versus 1.90 for PFOS, 5.72 versus 0.68 for PFOA). Studies on the occurrence and environmental behavior of organic pollutants in Bohai Sea increased dramatically in recent years, while the pollution profiles, levels, temporal trends, and transport mechanism of emerging organic pollutants in this area are still very limited. The data for some emerging chemicals such as TBBPA, a common brominated flame retardant, is not available in this area in spite of the fact that TBBPA has been found in other water areas $[49,50]$ and even Arctic area [51]. HBCD acted as a candidate chemical of Stockholm Convention now, but there are very limited data reported in this area. Up to now, only a few studies provided the pollution levels in water and marine sediment samples directly obtained in Bohai Sea. The possible reason may be (1) the low levels of these pollutants in water samples and (2) the difficulties to collect marine sediments. On the contrary, biological samples have been 
TABLE 1: Comparison of emerging organic pollutants in different matrix among Bohai Sea and other areas.

\begin{tabular}{|c|c|c|c|c|c|c|}
\hline & tion & PBDEs & PFOS & PFOA & $\mathrm{HBCD}$ & Sample matrix \\
\hline \multirow[t]{2}{*}{ China } & \multirow[t]{2}{*}{ Bohai Sea } & $\begin{array}{c}0.07-5.24[14] \\
0.22-0.9[15] \\
\text { nd-0.66 [17] } \\
\text { nd-0.87 [18] } \\
0.13-1.98[20]\end{array}$ & $\begin{array}{l}\text { nd-1.97 [23] } \\
\text { nd-4.3 [24] }\end{array}$ & $\begin{array}{l}\text { nd-0.54 [23] } \\
\text { nd-1.5 [23] }\end{array}$ & \multirow[b]{2}{*}{ nd-28.8 [36] } & \multirow[t]{2}{*}{ Sediment } \\
\hline & & $\begin{array}{c}0.31-2.73[14] \\
0.04-60.9[35] \\
0.01-20.4[36] \\
\end{array}$ & $\begin{array}{c}\text { nd- } 4.33[41] \\
\text { nd-268 (Ark shell } \\
\text { 0.94) [43] }\end{array}$ & $\begin{array}{c}\text { nd-126 [41] } \\
\text { nd-60.6 (Ark shell } \\
\text { 2.10) [43] }\end{array}$ & & \\
\hline \multirow[b]{2}{*}{ China } & \multirow[t]{2}{*}{$\begin{array}{l}\text { Other sea } \\
\text { areas }\end{array}$} & $\begin{array}{c}0.1-5.5[29] \\
\text { nd-8.0[58] } \\
0.04-4.48[59]\end{array}$ & $<0.1-11.91[60]$ & $1.84-34.01[55]$ & - & Sediment \\
\hline & & $\begin{array}{c}\text { Nd-2.20 [61] } \\
0.306 \text { (mussel, } \\
\text { average) (ww) [62] } \\
\text { 84-980 (small } \\
\text { cetaceans) (lw) } \\
{[63]}\end{array}$ & $\begin{array}{c}0.3-13.9(\mathrm{ww})[64] \\
\text { nd-1.69 (ww) [65] } \\
<0.0014-1.627 \\
(w w)[66] \\
0.6-2.0[67]\end{array}$ & $\begin{array}{c}\text { nd-1.67 (ww) [59] } \\
\text { nd-0.66(ww) [60] } \\
<0.0054-7.543 \\
(w w)[61] \\
\text { nd-2.2 [47] }\end{array}$ & $\begin{array}{c}4.7-380(\text { small } \\
\text { cetaceans) (lw) } \\
{[63]} \\
\text { nd-51 (lw) [68] }\end{array}$ & Biota \\
\hline \multirow[b]{2}{*}{ Japan } & & $0.05-3.6$ [69] & $\begin{array}{c}0.09-0.14[70] \\
0.13-1.4[71]\end{array}$ & $\begin{array}{c}0.84-1.1[70] \\
0.11-0.39[71]\end{array}$ & $0.056-2.3[69]$ & Sediment \\
\hline & & $\begin{array}{c}1.3-8.5(1 w)[72] \\
0.03-2.0(w w)[73]\end{array}$ & $\begin{array}{c}<0.3[70] \\
3.8[67]\end{array}$ & $\begin{array}{c}6.3-14 \text { (mussel) } \\
\quad(\text { ww) }[70] \\
3.4-8.1 \text { (oyster) } \\
\text { (ww) [70] } \\
4.3[67]\end{array}$ & $\begin{array}{c}0-36.9(\mathrm{ww})[74] \\
6.2-49(\mathrm{lw})[34] \\
<0.5-110(\mathrm{lw})[72] \\
0.3-10(\mathrm{ww})[73] \\
10-1400(\mathrm{lw})[68] \\
44.3 \text { (black-striped } \\
\text { mussel)-177 (green } \\
\text { crab) (lw) [75] }\end{array}$ & Biota \\
\hline \multirow[b]{2}{*}{ USA } & & $\begin{array}{c}\text { nd-212 [47] } \\
2.1-8[7] \\
\text { nd-560 [46] }\end{array}$ & $0.07-0.18[76]$ & $0.03-0.08$ [76] & $0.1-1.7[77]$ & Sediment \\
\hline & & $\begin{array}{c}\text { 9-106 [47] } \\
\text { 470-2260 (White } \\
\text { croaker) (lw) [77] } \\
30.4-4500 \\
\text { (Bottlenose } \\
\text { dolphin) (lw) [78] } \\
\text { 12.4-4190 (Bull } \\
\text { shark) (lw)[78] }\end{array}$ & $\begin{array}{c}1.4-96.8(\mathrm{ng} / \mathrm{mL} \\
\text { Sea turtle Plasma) } \\
{[79]} \\
0.31-39.0(\mathrm{ng} / \mathrm{mL} \\
\text { Sea turtle Plasma) } \\
{[80]}\end{array}$ & $\begin{array}{c}0.49-8.14(\mathrm{ng} / \mathrm{mL} \\
\text { Sea turtle Plasma) } \\
{[79]} \\
0.076-0.993(\text { Sea } \\
\text { turtle Plasma) [80] }\end{array}$ & $\begin{array}{c}\text { nd-4.5 (White } \\
\text { croaker) (lw) [77] } \\
0.460-72.6 \\
\text { (Bottlenose } \\
\text { dolphin) (lw) [78] } \\
\text { 9.15-413 (Bull } \\
\text { shark) (lw) [78] }\end{array}$ & Biota \\
\hline \multirow[b]{2}{*}{ Arctic } & \multirow[t]{2}{*}{ Area } & $0.107-0.297[51]$ & $\begin{array}{c}<0.04^{82} \\
\text { nd-0.11 [48] }\end{array}$ & $\begin{array}{c}0.017-0.13^{82} \\
\text { nd }[48]\end{array}$ & nd [51] & Sediment \\
\hline & & $\begin{array}{c}0.11(\mathrm{ww})[81] \\
0.06-0.19(\mathrm{ww})[51] \\
18.3-44.5(\text { eggs of } \\
\text { ivory gulls) (lw) } \\
{[82]}\end{array}$ & $\begin{array}{l}\text { 0.12-5.4 (Cod } \\
\text { muscle) (ww) [83] } \\
<0.3-1.3(\text { Salmon } \\
\text { muscle) (ww) [83] }\end{array}$ & $\begin{array}{l}0.14-0.03(\text { Cod } \\
\text { muscle) }(w w)[83] \\
<0.08-1.2(\text { Salmon } \\
\text { muscle) (ww) [83] }\end{array}$ & $\begin{array}{c}14.7 \text { (Polar Cod) } \\
\text { (lw) [51] } \\
2.1-3.8 \text { (eggs of } \\
\text { ivory gulls) (lw) } \\
{[82]}\end{array}$ & Biota \\
\hline
\end{tabular}

(ng/g dw ww: wet weight based; lw: lipid weight based).

used extensively to assess the organic pollutant levels, source identification, biotransformation, and temporal trends due to the relative higher concentrations and easier collection [35, 36, 52-54]. Certain biota (especially mussels) have been used as indicator for monitoring emerging organic pollutants in the Bohai Sea, which allowed us to compare the status of emerging organic pollution among different countries and regions. Bohai Sea is a relative closed ecological system, which make it an ideal place for investigating the trophodynamic behavior of organic pollutants $[55,56]$. In present stage, few studies were related to emerging pollutants transportation along food web in this area, whereas the bioaccumulation and biomagnifications of these emerging organic pollutants were still not clear. As for temporal issue, Zhu et al. [36] reported a decline trend of PBDEs in mollusks during 2003 to 2010 (from 7.0 to $1.0 \mathrm{ng} / \mathrm{g} \mathrm{dw}$ ). However, there were no data available to evaluate the temporal trends for other emerging pollutants in this area. Thus it is necessary to select certain bioindicators from Bohai Sea to set up a long term monitoring program. Besides, spatial monitoring in the sea and along 
the coastal areas is also needed. With the GPS information and congener patterns from all the sampling sites, it is able to describe an "emerging POPs map system" in this special area, which would be very helpful to trace the pollution sources. The idea has already been used in legacy POPs [57]. Through the temporal and spatial trends of legacy and emerging pollutants, on one hand, we can track the changing pollutant profiles and adjust the management policy. On the other hand, it can also provide a data basis for the environmental safety of China and Stockholm Convention implementation.

\section{Conflict of Interests}

The authors declare that there is no conflict of interests regarding the publication of this paper.

\section{Acknowledgments}

Financial support for this study was obtained from the State Key Laboratory of Environmental Chemistry and Ecotoxicology (KF2012-08) and the National Natural Science Foundation of China (no. 21307157).

\section{References}

[1] http://chm.pops.int/Convention/ThePOPs/tabid/673/Default .aspx.

[2] M. la Farré, S. Pérez, L. Kantiani, and D. Barceló, "Fate and toxicity of emerging pollutants, their metabolites and transformation products in the aquatic environment," TrAC Trends in Analytical Chemistry, vol. 27, no. 11, pp. 991-1007, 2008.

[3] A. Covaci, S. Harrad, M. A.-E. Abdallah et al., "Novel brominated flame retardants: a review of their analysis, environmental fate and behaviour," Environment International, vol. 37, no. 2, pp. 532-556, 2011.

[4] S. D. Richardson and T. A. Ternes, "Water analysis: emerging contaminants and current issues," Analytical Chemistry, vol. 83, no. 12, pp. 4616-4648, 2011.

[5] L. N. Liang, B. He, G. B. Jiang, D. Y. Chen, and Z. W. Yao, "Evaluation of mollusks as biomonitors to investigate heavy metal contaminations along the Chinese Bohai Sea," Science of the Total Environment, vol. 324, no. 1-3, pp. 105-113, 2004.

[6] W. Hu, T. Wang, J. S. Khim et al., "HCH and DDT in sediments from marine and adjacent riverine areas of North Bohai Sea, China," Archives of Environmental Contamination and Toxicology, vol. 59, no. 1, pp. 71-79, 2010.

[7] P. Zhang, J. Song, and H. Yuan, "Persistent organic pollutant residues in the sediments and mollusks from the Bohai Sea coastal areas, North China: an overview," Environment International, vol. 35, no. 3, pp. 632-646, 2009.

[8] L.-N. Liang, J.-B. Shi, B. He, G.-B. Jiang, and C.-G. Yuan, "Investigation of methylmercury and total mercury contamination in mollusk samples collected from coastal sites along the Chinese Bohai Sea," Journal of Agricultural and Food Chemistry, vol. 51, no. 25, pp. 7373-7378, 2003.

[9] R. Q. Yang, Z. W. Yao, G. B. Jiang, Q. F. Zhou, and J. Y. Liu, "HCH and DDT residues in molluscs from Chinese Bohai coastal sites," Marine Pollution Bulletin, vol. 48, no. 7-8, pp. 795-799, 2004 .
[10] Y. Wang, L. Liang, J. Shi, and G. Jiang, "Study on the contamination of heavy metals and their correlations in mollusks collected from coastal sites along the Chinese Bohai Sea," Environment International, vol. 31, no. 8, pp. 1103-1113, 2005.

[11] X. Zhao, M. Zheng, L. Liang, Q. Zhang, Y. Wang, and G. Jiang, "Assessment of PCBs and PCDD/Fs along the Chinese Bohai Sea coastline using mollusks as bioindicators," Archives of Environmental Contamination and Toxicology, vol. 49, pp. 178185, 2005.

[12] R. Yang, Q. Zhou, J. Liu, and G. Jiang, "Butyltins compounds in molluscs from Chinese Bohai coastal waters," Food Chemistry, vol. 97, no. 4, pp. 637-643, 2006.

[13] R. Yang, D. Cao, Q. Zhou, Y. Wang, and G. Jiang, "Distribution and temporal trends of butyltins monitored by molluscs along the Chinese Bohai coast from 2002 to 2005," Environment International, vol. 34, no. 6, pp. 804-810, 2008.

[14] Z. Wang, X. Ma, Z. Lin, G. Na, and Z. Yao, "Congener specific distributions of polybrominated diphenyl ethers (PBDEs) in sediment and mussel (Mytilus edulis) of the Bo Sea, China," Chemosphere, vol. 74, no. 7, pp. 896-901, 2009.

[15] X. Pan, J. Tang, J. Li, Z. Guo, and G. Zhang, "Levels and distributions of PBDEs and PCBs in sediments of the Bohai Sea, North China," Journal of Environmental Monitoring, vol. 12, no. 6, pp. 1234-1241, 2010.

[16] T. Nouira, C. Risso, L. Chouba, H. Budzinski, and H. Boussetta, "Polychlorinated biphenyls (PCBs) and polybrominated diphenyl ethers (PBDEs) in surface sediments from Monastir Bay (Tunisia, Central Mediterranean): occurrence, distribution and seasonal variations," Chemosphere, vol. 93, no. 3, pp. 487493, 2013.

[17] X. Pan, J. Tang, J. Li, G. Zhong, Y. Chen, and G. Zhang, "Polybrominated diphenyl ethers (PBDEs) in the riverine and marine sediments of the Laizhou Bay area, North China," Journal of Environmental Monitoring, vol. 13, no. 4, pp. 886-893, 2011.

[18] B. Zheng, X. Zhao, L. Liu et al., "Effects of hydrodynamics on the distribution of trace persistent organic pollutants and macrobenthic communities in Bohai Bay," Chemosphere, vol. 84, no. 3, pp. 336-341, 2011.

[19] X. Zhao, B. Zheng, Y. Qin, L. Jiao, and L. Zhang, "Grain size effect on PBDE and PCB concentrations in sediments from the intertidal zone of Bohai Bay, China," Chemosphere, vol. 81, no. 8, pp. 1022-1026, 2010.

[20] X. Zhao, H. Zhang, Y. Ni et al., "Polybrominated diphenyl ethers in sediments of the Daliao River Estuary, China: levels, distribution and their influencing factors," Chemosphere, vol. 82, no. 9, pp. 1262-1267, 2011.

[21] C. Chen, T. Wang, J. S. Khim et al., "Perfluorinated compounds in water and sediment from coastal regions of the northern Bohai Sea, China," Chemistry and Ecology, vol. 27, no. 2, pp. 165176, 2011.

[22] A. M. Becker, S. Gerstmann, and H. Frank, "Perfluorooctane surfactants in waste waters, the major source of river pollution," Chemosphere, vol. 72, no. 1, pp. 115-121, 2008.

[23] T. Wang, Y. Lu, C. Chen et al., "Perfluorinated compounds in estuarine and coastal areas of north Bohai Sea, China," Marine Pollution Bulletin, vol. 62, no. 8, pp. 1905-1914, 2011.

[24] T. Wang, Y. Lu, C. Chen, J. E. Naile, J. S. Khim, and J. P. Giesy, "Perfluorinated compounds in a coastal industrial area of Tianjin, China," Environmental Geochemistry and Health, vol. 34, no. 3, pp. 301-311, 2012. 
[25] W. Liu, Y. Jin, X. Quan et al., "Perfluorosulfonates and perfluorocarboxylates in snow and rain in Dalian, China," Environment International, vol. 35, no. 4, pp. 737-742, 2009.

[26] X. Ju, Y. Jin, K. Sasaki, and N. Saito, "Perfluorinated surfactants in surface, subsurface water and microlayer from Dalian coastal waters in China," Environmental Science and Technology, vol. 42, no. 10, pp. 3538-3542, 2008.

[27] X. Pan, J. Tang, Y. Chen, J. Li, and G. Zhang, "Polychlorinated naphthalenes (PCNs) in riverine and marine sediments of the Laizhou Bay area, North China," Environmental Pollution, vol. 159, no. 12, pp. 3515-3521, 2011.

[28] X. Zhao, H. Zhang, J. Fan et al., "Dioxin-like compounds in sediments from the Daliao River Estuary of Bohai Sea: distribution and their influencing factors," Marine Pollution Bulletin, vol. 62, no. 5, pp. 918-925, 2011.

[29] J. Pan, Y.-L. Yang, Q. Xu, D.-Z. Chen, and D.-L. Xi, “PCBs, PCNs and PBDEs in sediments and mussels from Qingdao coastal sea in the frame of current circulations and influence of sewage sludge," Chemosphere, vol. 66, no. 10, pp. 1971-1982, 2007.

[30] L. Guo, Research centor for eco-environmental sciences [Ph.D. thesis], Chinese Academy of Sciences, 2008, (Chinese).

[31] P. A. Helm, S. B. Gewurtz, D. M. Whittle, C. H. Marvin, A. T. Fisk, and G. T. Tomy, "Occurrence and biomagnification of polychlorinated naphthalenes and non- and mono-ortho PCBs in Lake Ontario sediment and biota," Environmental Science and Technology, vol. 42, no. 4, pp. 1024-1031, 2008.

[32] Y. Zhang, Y. Ruan, H. Sun, L. Zhao, and Z. Gan, "Hexabromocyclododecanes in surface sediments and a sediment core from Rivers and Harbor in the northern Chinese city of Tianjin," Chemosphere, vol. 90, pp. 1610-1616, 2013.

[33] H. Li, Q. Zhang, P. Wang et al., "Levels and distribution of hexabromocyclododecane (HBCD) in environmental samples near manufacturing facilities in Laizhou Bay area, East China," Journal of Environmental Monitoring, vol. 14, pp. 2591-2597, 2012.

[34] K. Ramu, N. Kajiwara, A. Sudaryanto et al., "Asian mussel watch program: contamination status of polybrominated diphenyl ethers and organochlorines in coastal waters of Asian countries," Environmental Science and Technology, vol. 41, no. 13, pp. 4580-4586, 2007.

[35] Y. Wang, T. Wang, A. Li et al., "Selection of bioindicators of polybrominated diphenyl ethers, polychlorinated biphenyls, and organochlorine pesticides in mollusks in the Chinese Bohai Sea," Environmental Science and Technology, vol. 42, no. 19, pp. 7159-7165, 2008.

[36] N. Zhu, A. Li, T. Wang et al., "Tris(2,3-dibromopropyl) isocyanurate, hexabromocyclododecanes, and polybrominated diphenyl ethers in mollusks from Chinese Bohai Sea "' Environmental Science \& Technology, vol. 46, pp. 7174-7181, 2012.

[37] J. Jin, W. Liu, Y. Wang, and X. Yan Tang, "Levels and distribution of polybrominated diphenyl ethers in plant, shellfish and sediment samples from Laizhou Bay in China," Chemosphere, vol. 71, no. 6, pp. 1043-1050, 2008.

[38] Y. Wan, J. Hu, K. Zhang, and L. An, "Trophodynamics of polybrominated diphenyl ethers in the marine food web of Bohai Bay, North China," Environmental Science \& Technology, vol. 42, pp. 1078-1083, 2008.

[39] Y.-P. Liu, J.-G. Li, Y.-F. Zhao, S. Wen, F.-F. Huang, and Y.-N. $\mathrm{Wu}$, "Polybrominated diphenyl ethers (PBDEs) and indicator polychlorinated biphenyls (PCBs) in marine fish from four areas of China," Chemosphere, vol. 83, no. 2, pp. 168-174, 2011.

[40] S. Tian, L. Zhu, and M. Liu, "Bioaccumulation and distribution of polybrominated diphenyl ethers in marine species from
Bohai Bay, China," Environmental Toxicology and Chemistry, vol. 29, no. 10, pp. 2278-2285, 2010.

[41] Y. Pan, Y. Shi, Y. Wang, Y. Cai, and G. Jiang, "Investigation of perfluorinated compounds (PFCs) in mollusks from coastal waters in the Bohai Sea of China," Journal of Environmental Monitoring, vol. 12, no. 2, pp. 508-513, 2010.

[42] C. Chen, T. Wang, J. E. Naile et al., "Perfluorinated Compounds in Aquatic Products from Bohai Bay, Tianjin, China," Human and Ecological Risk Assessment, vol. 17, no. 6, pp. 1279-1291, 2011.

[43] L. Yang, S. Tian, L. Zhu, Z. Liu, and Y. Zhang, "Bioaccumulation and distribution of perfloroalkyl acids in seafood products from Bohai Bay, China," Environmental Toxicology and Chemistry, vol. 31, pp. 1972-1979, 2012.

[44] B. Yuan, W. Thanh, N. Zhu et al., "Short chain chlorinated paraffins in mollusks from coastal waters in the Chinese Bohai Sea," Environmental Science \& Technology, vol. 46, pp. 64896496, 2012.

[45] Y. Wang, G. Jiang, P. K. S. Lam, and A. Li, "Polybrominated diphenyl ether in the East Asian environment: a critical review," Environment International, vol. 33, no. 7, pp. 963-973, 2007.

[46] N. G. Dodder, K. A. Maruya, G. G. Lauenstein, J. Ramirez, K. J. Ritter, and K. C. Schiff, "Distribution and sources of polybrominated diphenyl ethers in the Southern California Bight," Environmental Toxicology and Chemistry, vol.31, pp. 2239-2245, 2012.

[47] D. R. Oros, D. Hoover, F. Rodigari, D. Crane, and J. Sericano, "Levels and distribution of polybrominated diphenyl ethers in water, surface sediments, and bivalves from the San Francisco," Environmental Science and Technology, vol. 39, no. 1, pp. 33-41, 2005.

[48] C. M. Butt, U. Berger, R. Bossi, and G. T. Tomy, "Levels and trends of poly- and perfluorinated compounds in the arctic environment," Science of the Total Environment, vol. 408, no. 15, pp. 2936-2965, 2010.

[49] J. Xu, Y. Zhang, C. Guo, Y. He, L. Li, and W. Meng, "Levels and distribution of tetrabromobisphenol A and hexabromocyclododecane in Taihu Lake, China," Environmental Toxicology and Chemistry, vol. 32, pp. 2249-2255, 2013.

[50] G. Qu, A. Liu, T. Wang et al., "Identification of tetrabromobisphenol A allyl ether and tetrabromobisphenol A 2,3-dibromopropyl ether in the ambient environment near a manufacturing site and in mollusks at a Coastal Region," Environmental Science \& Technology, vol. 47, pp. 4760-4767, 2013.

[51] C. A. de Wit, M. Alaee, and D. C. G. Muir, "Levels and trends of brominated flame retardants in the Arctic," Chemosphere, vol. 64, no. 2, pp. 209-233, 2006.

[52] Y. Wang, R. Yang, and G. Jiang, "Investigation of organochlorine pesticides (OCPs) in mollusks collected from coastal sites along the Chinese Bohai Sea from 2002 to 2004," Environmental Pollution, vol. 146, no. 1, pp. 100-106, 2007.

[53] I. Monirith, D. Ueno, S. Takahashi et al., "Asia-Pacific mussel watch: monitoring contamination of persistent organochlorine compounds in coastal waters of Asian countries," Marine Pollution Bulletin, vol. 46, no. 3, pp. 281-300, 2003.

[54] K. Ramu, N. Kajiwara, A. Sudaryanto et al., "Asian mussel watch program: contamination status of polybrominated diphenyl ethers and organochlorines in coastal waters of Asian countries," Environmental Science and Technology, vol. 41, no. 13, pp. 4580-4586, 2007.

[55] Y. Wan, J. Y. Hu, M. Yang et al., "Characterization of trophic transfer for polychlorinated dibenzo-p-dioxins, dibenzofurans, 
non- and mono-ortho polychlorinated biphenyls in the marine food web of Bohai Bay, North China," Environmental Science \& Technology, vol. 39, pp. 2417-2425, 2005.

[56] Y. Wan, X. Jin, J. Hu, and F. Jin, “Trophic dilution of polycyclic aromatic hydrocarbons (PAHs) in a marine food web from Bohai Bay, North China," Environmental Science and Technology, vol. 41, no. 9, pp. 3109-3114, 2007.

[57] E. J. Reiner, R. E. Clement, A. B. Okey, and C. H. Marvin, "Advances in analytical techniques for polychlorinated dibenzo-p-dioxins, polychlorinated dibenzofurans and dioxinlike PCBs," Analytical and Bioanalytical Chemistry, vol. 386, no. 4, pp. 791-806, 2006.

[58] Y. Li, T. Lin, Y. Chen, L. Hu, Z. Guo, and G. Zhang, "Polybrominated diphenyl ethers (PBDEs) in sediments of coastal East China sea: occurrence, distribution and mass inventory," Environmental Pollution, vol. 171, pp. 155-161, 1987.

[59] S. Chen, B. Mai, E. Zeng et al., "Polybrominated diphenyl ethers (PBDEs) in surficial sediments of the Pearl River Delta and adjacent South China Sea," Acta Scientiae Circumstantiae, vol. 25, no. 9, pp. 1265-1271, 2005 (Chinese).

[60] S. Zhao, P. Cao, C. Zhu et al., "Pollution characteristics of PFOS and PFOA in water and sediment samples from Wenzhou inshore," Marine Environmental Science, vol. 31, pp. 221-224, 2012 (Chinese).

[61] J. Guo, F. Wu, R. Shen, and E. Y. Zeng, "Dietary intake and potential health risk of DDTs and PBDEs via seafood consumption in South China," Ecotoxicology and Environmental Safety, vol. 73, no. 7, pp. 1812-1819, 2010.

[62] J.-Y. Guo, F.-C. Wu, B.-X. Mai, X.-J. Luo, and E. Y. Zeng, "Polybrominated diphenyl ethers in seafood products of South China," Journal of Agricultural and Food Chemistry, vol. 55, no. 22, pp. 9152-9158, 2007.

[63] T. Isobe, K. Ramu, N. Kajiwara et al., "Isomer specific determination of hexabromocyclododecanes (HBCDs) in small cetaceans from the South China Sea-levels and temporal variation," Marine Pollution Bulletin, vol. 54, no. 8, pp. 1139-1145, 2007.

[64] A. Gulkowska, Q. Jiang, M. K. So, S. Taniyasu, P. K. S. Lam, and N. Yamashita, "Persistent perfluorinated acids in seafood collected from two cities of China," Environmental Science and Technology, vol. 40, no. 12, pp. 3736-3741, 2006.

[65] T. Zhang, H. Sun, Y. Lin et al., "Perfluorinated compounds in human blood, water, edible freshwater fish, and seafood in China: daily intake and regional differences in human exposures," Journal of Agricultural and Food Chemistry, vol. 59, no. 20, pp. 11168-11176, 2011.

[66] Y. Wu, Y. Wang, J. Li et al., "Perfluorinated compounds in seafood from coastal areas in China," Environment International, vol. 42, no. 1, pp. 67-71, 2012.

[67] M. K. So, S. Taniyasu, P. K. S. Lam, G. J. Zheng, J. P. Giesy, and N. Yamashita, "Alkaline digestion and solid phase extraction method for perfluorinated compounds in mussels and oysters from south China and Japan," Archives of Environmental Contamination and Toxicology, vol. 50, no. 2, pp. 240-248, 2006.

[68] T. Isobe, S. P. Ogawa, K. Ramu, A. Sudaryanto, and S. Tanabe, "Geographical distribution of non-PBDE-brominated flame retardants in mussels from Asian coastal waters," Environmental Science and Pollution Research, vol. 19, no. 8, pp. 3107-3117, 2012.

[69] N. H. Minh, T. Isobe, D. Ueno et al., "Spatial distribution and vertical profile of polybrominated diphenyl ethers and hexabromocyclododecanes in sediment core from Tokyo Bay,
Japan," Environmental Pollution, vol. 148, no. 2, pp. 409-417, 2007.

[70] H. Nakata, K. Kannan, T. Nasu, H.-S. Cho, E. Sinclair, and A. Takemura, "Perfluorinated contaminants in sediments and aquatic organisms collected from shallow water and tidal flat areas of the Ariake Sea, Japan: environmental fate of perfluorooctane sulfonate in aquatic ecosystems," Environmental Science and Technology, vol. 40, no. 16, pp. 4916-4921, 2006.

[71] A. M. Peck, R. S. Pugh, A. Moors et al., "Hexabromocyclododecane in white-sided dolphins: temporal trend and stereoisomer distribution in tissues," Environmental Science and Technology, vol. 42, no. 7, pp. 2650-2655, 2008.

[72] S. Takahashi, T. Oshihoi, K. Ramu et al., "Organohalogen compounds in deep-sea fishes from the western North Pacific, offTohoku, Japan: contamination status and bioaccumulation profiles," Marine Pollution Bulletin, vol. 60, no. 2, pp. 187-196, 2010.

[73] D. Ueno, T. Isobe, K. Ramu et al., "Spatial distribution of hexabromocyclododecanes (HBCDs), polybrominated diphenyl ethers (PBDEs) and organochlorines in bivalves from Japanese coastal waters," Chemosphere, vol. 78, no. 10, pp. 1213-1219, 2010.

[74] R. Nakagawa, S. Murata, Y. Ashizuka, Y. Shintani, T. Hori, and T. Tsutsumi, "Hexabromocyclododecane determination in seafood samples collected from Japanese coastal areas," Chemosphere, vol. 81, no. 4, pp. 445-452, 2010.

[75] K. Mizukawa, H. Takada, I. Takeuchi, T. Ikemoto, K. Omori, and K. Tsuchiya, "Bioconcentration and biomagnification of polybrominated diphenyl ethers (PBDEs) through lower-trophiclevel coastal marine food web," Marine Pollution Bulletin, vol. 58, no. 8, pp. 1217-1224, 2009.

[76] J. P. Benskin, M. G. Ikonomou, F. A. P. C. Gobas, M. B. Woudneh, and J. R. Cosgrove, "Observation of a novel PFOSprecursor, the perfluorooctane sulfonamido ethanol-based phosphate (SAmPAP) diester, in marine sediments," Environmental Science \& Technology, vol. 46, pp. 6505-6514, 2012.

[77] S. L. Klosterhaus, H. M. Stapleton, M. J. La Guardia, and D. J. Greig, "Brominated and chlorinated flame retardants in San Francisco Bay sediments and wildlife," Environment International, vol. 47, pp. 56-65, 2012.

[78] B. Johnson-Restrepo, D. H. Adams, and K. Kannan, "Tetrabromobisphenol A (TBBPA) and hexabromocyclododecanes (HBCDs) in tissues of humans, dolphins, and sharks from the United States," Chemosphere, vol. 70, no. 11, pp. 1935-1944, 2008.

[79] J. M. Keller, K. Kannan, S. Taniyasu et al., "Perfluorinated compounds in the plasma of loggerhead and Kemp's ridley sea turtles from the southeastern coast of the United States," Environmental Science and Technology, vol. 39, no. 23, pp. 9101-9108, 2005.

[80] S. G. O’Connell, M. Arendt, A. Segars et al., “Temporal and spatial trends of perfluorinated compounds in juvenile loggerhead sea turtles (Caretta caretta) along the east coast of the United States," Environmental Science and Technology, vol. 44, no. 13, pp. 5202-5209, 2010.

[81] J. H. Christensen, M. Glasius, M. Pécseli, J. Platz, and G. Pritzl, "Polybrominated diphenyl ethers (PBDEs) in marine fish and blue mussels from southern Greenland," Chemosphere, vol. 47, no. 6, pp. 631-638, 2002.

[82] B. M. Braune, M. L. Mallory, H. Grant Gilchrist, R. J. Letcher, and K. G. Drouillard, "Levels and trends of organochlorines and brominated flame retardants in Ivory Gull eggs from the Canadian Arctic, 1976 to 2004," Science of the Total Environment, vol. 378, no. 3, pp. 403-417, 2007. 
[83] B. C. Kelly, M. G. Ikonomou, J. D. Blair et al., "Perfluoroalkyl contaminants in an arctic marine food web: trophic magnification and wildlife exposure," Environmental Science and Technology, vol. 43, no. 11, pp. 4037-4043, 2009.

[84] J. Hu, Y. Wan, B. Shao et al., "Occurrence of trace organic contaminants in Bohai Bay and its adjacent Nanpaiwu River, North China," Marine Chemistry, vol. 95, no. 1-2, pp. 1-13, 2005.

[85] L. Hu, G. Zhang, B. Zheng, Y. Qin, T. Lin, and Z. Guo, "Occurrence and distribution of organochlorine pesticides (OCPs) in surface sediments of the Bohai Sea, China," Chemosphere, vol. 77, no. 5, pp. 663-672, 2009.

[86] W. Liu, J. Chen, X. Lin, S. Xu, and S. Tao, "Spatial distribution characteristics of DDTs, PCBs and phthalates in surface sediments from Bohai Sea, China," Acta Scientiae Circumstantiae, vol. 25, pp. 58-63, 2005 (Chinese).

[87] M. Ma, Z. Feng, C. Guan, Y. Ma, H. Xu, and H. Li, "DDT, PAH and PCB in sediments from the intertidal zone of the Bohai Sea and the Yellow Sea," Marine Pollution Bulletin, vol. 42, no. 2, pp. 132-136, 2001.

[88] W. X. Liu, J. L. Chen, X. M. Lin, and S. Tao, "Distribution and characteristics of organic micropollutants in surface sediments from Bohai Sea," Environmental Pollution, vol. 140, no. 1, pp. 48, 2006.

[89] J. Pan, Y. Yang, C. Geng, L. W. Y. Yeung, X. Cao, and T. Dai, "Polychlorinated biphenyls, polychlorinated dibenzo-p-dioxins and dibenzofurans in marine and lacustrine sediments from the Shandong Peninsula, China," Journal of Hazardous Materials, vol. 176, no. 1-3, pp. 274-279, 2010. 

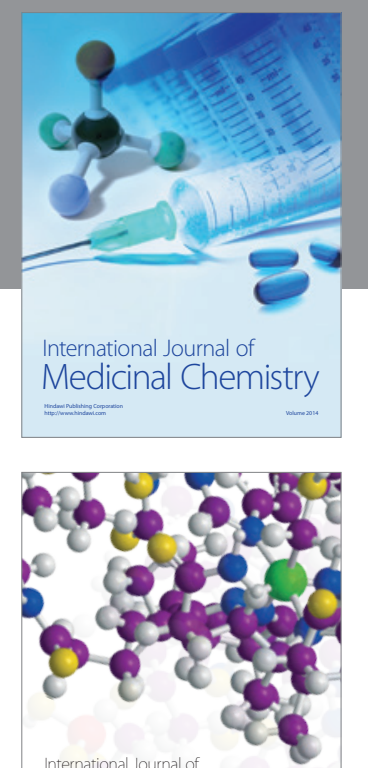

\section{Carbohydrate} Chemistry

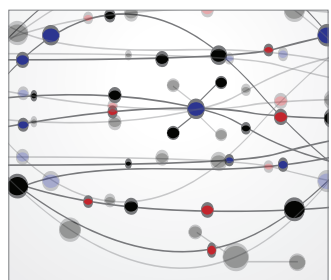

The Scientific World Journal
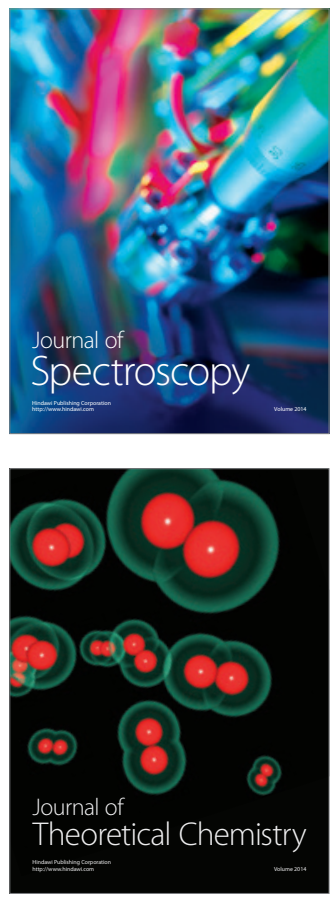
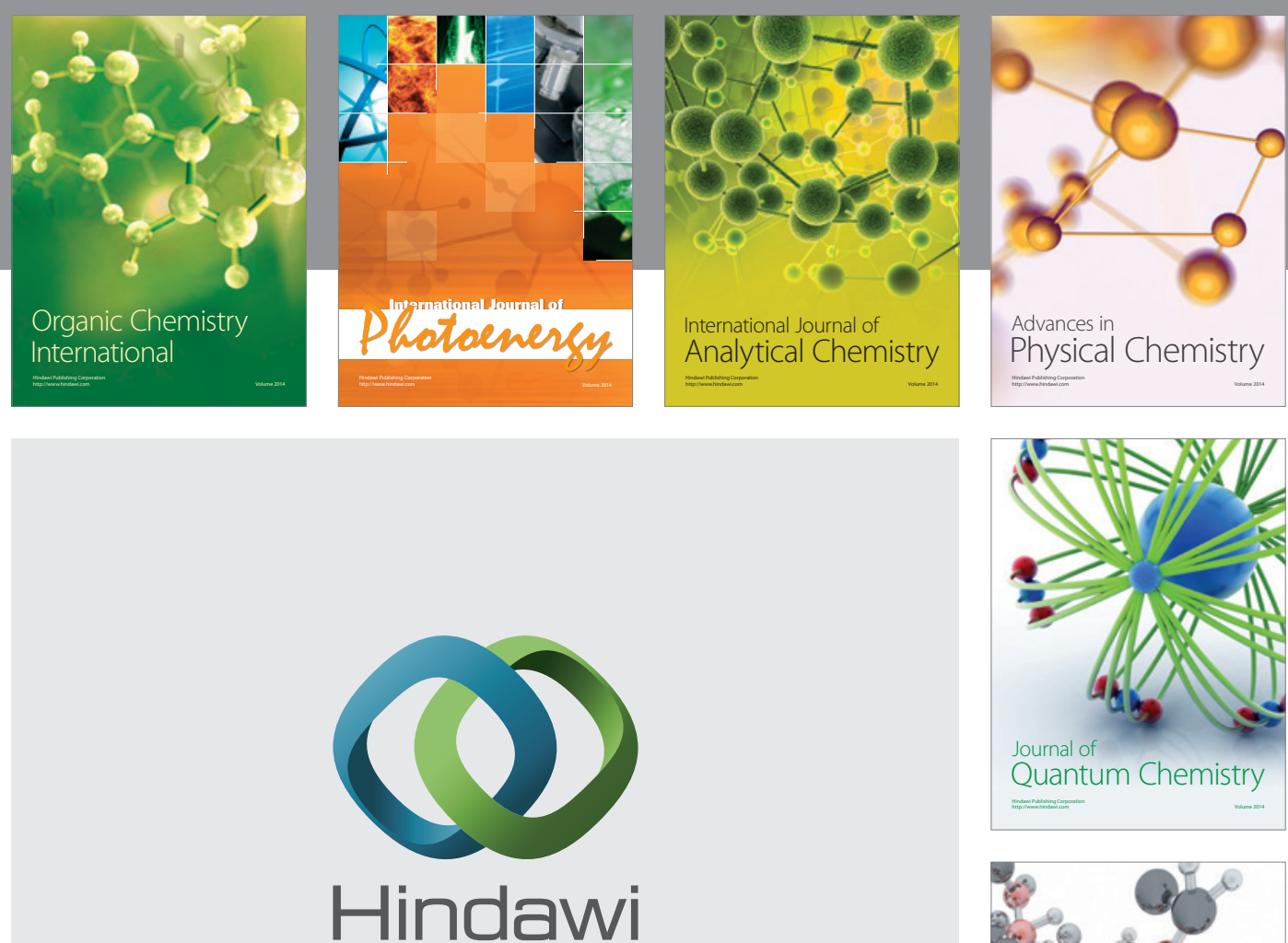

Submit your manuscripts at

http://www.hindawi.com

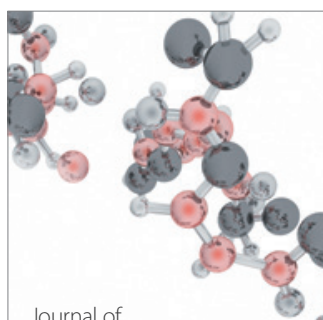

Analytical Methods

in Chemistry

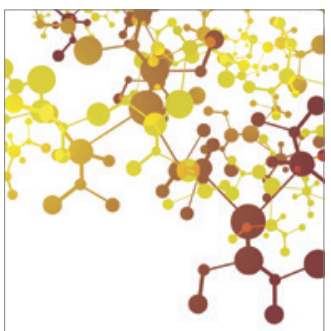

Journal of

Applied Chemistry

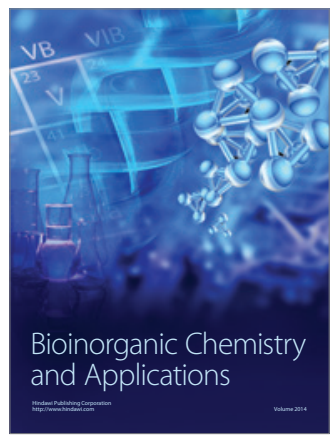

Inorganic Chemistry
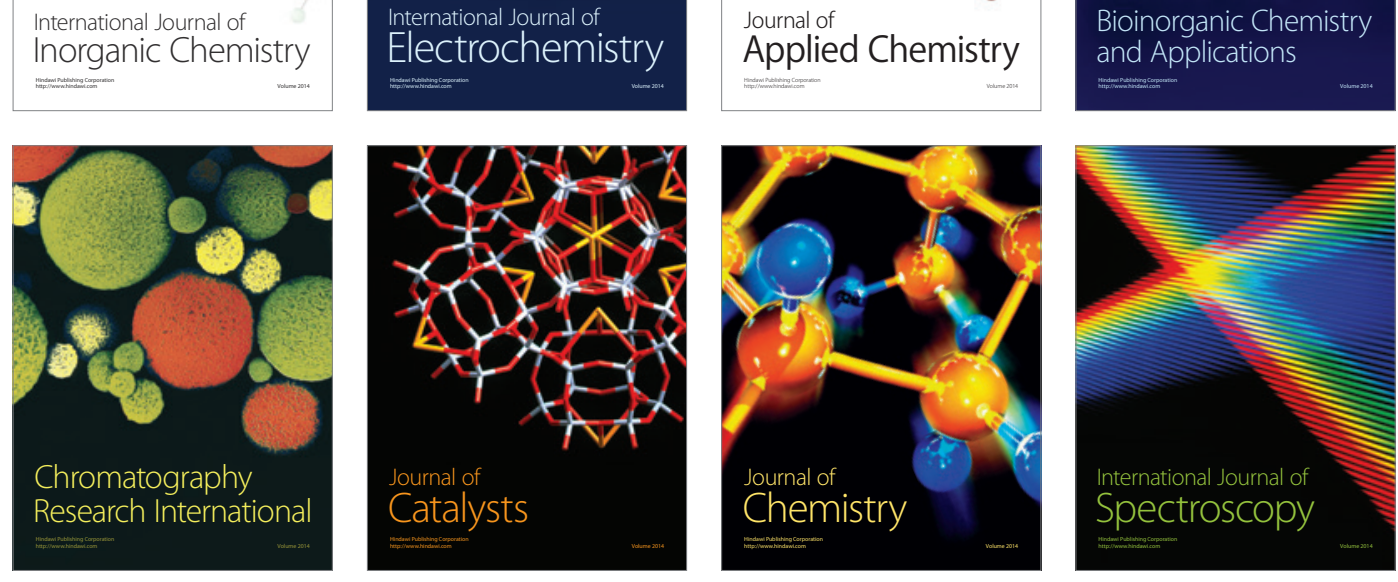